\title{
HUBUNGAN TINGKAT PENGETAHUAN TENTANG PENYAKIT DEMAM BERDARAH DENGUE DENGAN TINDAKAN PEMBERANTASAN SARANG NYAMUK
}

\author{
Budi Kristanto, Rahayu Setyaningsih \\ AKPER PANTI KOSALA SURAKARTA, Sukoharjo, Jawa Tengah, Indonesia
}

\begin{abstract}
Abstrak
Latar Belakang. Data Kementerian Kesehatan RI bulan Februari 2019, mencatat 16.692 kasus DBD dengan 169 orang meninggal, hal ini mengalami peningkatan dibandingkan dengan tahun 2018 yang hanya 13.683 kasus dengan 133 meninggal dunia. Jawa Tengah adalah salah satu provinsi dengan kasus terbanyak dan diantaranya Desa Kenokorejo Kabupaten Sukoharjo dimana hampir setiap tahunnya ada kasus DBD.

Tujuan Penelitian. Mengetahui hubungan antara tingkat pengetahuan tentang penyakit Demam Berdarah Dengue dengan tindakan Pemberantasan Sarang Nyamuk (PSN).

Subjek dan Metode. Penelitian ini analitik observasional dengan desain korelasi dan pendekatan cross sectional. Responden adalah 47 warga Desa Kenokorejo diambil dengan sampling jenuh. Analisis data menggunakan Pearson Correlation.

Hasil. Mayoritas responden memiliki pengetahuan kategori baik 95,74\%, sedangkan kurang sebesar 4,25\%, mayoritas responden dengan tindakan PSN baik yaitu 53,19\%, dan kategori kurang $6,38 \%$.

Kesimpulan. Tidak ada hubungan antara tingkat pengetahuan DBD dengan tindakan PSN $(p=0,367)$.

Kata kunci : demam berdarah dengue, pemberantasan sarang nyamuk, pengetahuan

\section{THE RELATIONSHIP BETWEEN THE LEVEL OF KNOWLEDGE ABOUT DENGUE HEMORRHAGIC FEVER WITH MOSQUITO ERADICATIONS}

\begin{abstract}
Background. According to Indonesian Ministry of Health in February 2019, there were 16,692 cases DHF with 169 deaths, this has increased compared to 2018 which only 13,683 cases with 133 died. Central Java is one of the provinces with the most cases and including Kenokorejo Village Sukoharjo Regency where almost every year there are dengue cases.

The Aim of the Study. To Know the relationship between the level of knowledge about Dengue Hemorrhagic Fever and the eradication of mosquito nests.

Subject and Method. Observational analytic research, correlation design with cross sectional approach. Respondents were 47 Residents of the Village of Kenokorejo taken by sampling saturation. Data were analyzed using Pearson Correlation.

Result. The majority of respondents have good category knowledge of $95.74 \%$, while less than $4.25 \%$, the majority of respondents with good PSN actions are $53.19 \%$, and categories of less $6.38 \%$.

Conclusion. There is no relationship between the level of DHF knowledge with mosquito eradication $(p=0.367)$.

Keywords: dengue hemorrhagic fever, eradication of mosquito nests, knowledge

Korespondensi: Budi Kristanto. AKPER PANTI KOSALA SURAKARTA. Jalan Raya SoloBaki Km. 4 Gedangan, Grogol, Sukoharjo, Jawa Tengah. Email: budikrist18@gmail.com.
\end{abstract}




\section{LATAR BELAKANG}

Demam Berdarah Dengue (DBD) adalah penyakit yang menyerang anak dan orang dewasa yang disebabkan oleh virus dengan manifestasi berupa demam akut, perdarahan, nyeri otot dan sendi. Dengue adalah suatu infeksi Arbovirus (Artropod Born Virus) yang akut ditularkan oleh nyamuk Aedes Aegypti atau oleh Aedes Albopictus (Lestari, 2016).

Dari data Kemenkes RI tercatat bahwa per tanggal 3 Februari 2019 adalah sebanyak 16.692 kasus dengan 169 orang yang meninggal dunia. Hal ini mengalami peningkatan dari data sebelumnya, per tanggal 29 Januari 2019 hanya 13.683 kasus dengan 133 jiwa yang meninggal dunia. Wilayah dengan kasus DBD terbanyak ada di wilayah Jawa Timur, Jawa Tengah, NTT dan Kupang (Depkes RI, 2019).

Meskipun angka kejadian penyakit DBD setiap tahun mengalami fluktuasi, namun penyakit DBD masih merupakan permasalahan yang serius di Provinsi Jawa Tengah, terbukti 35 kabupaten/kota sudah pernah terjangkit penyakit DBD. Angka kesakitan/Incidence Rate (IR) DBD di Provinsi Jawa Tengah pada tahun 2017 sebesar 21,68 per 100.000 penduduk. Hal ini berarti IR DBD di Jawa Tengah lebih rendah dari target nasional sebesar $<51 / 100.000$ penduduk dan target Renstra sebesar $<48 / 100.000$ (Dinkes Provinsi Jawa Tengah, 2017).

Tingginya angka kesakitan DBD disebabkan karena adanya iklim tidak stabil dan curah hujan cukup banyak pada musim penghujan merupakan sarana perkembangbiakan nyamuk Aedes aegypti yang cukup potensial. Selain itu juga didukung dengan tidak maksimalnya tindakan atau kegiatan Pemberantasan Sarang Nyamuk (PSN) di masyarakat sehingga menimbulkan Kejadian Luar Biasa
(KLB) penyakit DBD di beberapa kota (Dinkes Provinsi Jawa Tengah, 2017).

Salah satu faktor penyebab tingginya kejadian DBD adalah pengetahuan masyarakat yang masih terbatas mengenai pentingnya Pemberantasan Sarang Nyamuk (PSN). Hal tersebut sesuai dengan penelitian yang dilakukan oleh Nuryanti (2013), diperoleh hasil bahwa salah satu variabel yang berhubungan dengan tindakan Pemberantasan Sarang Nyamuk adalah pengetahuan $(p=0,001)$.

Penelitian yang dilakukan oleh Sejati, Sulisetyawati dan Nurhayati (2014) diketahui bahwa terdapat hubungan pengetahuan tentang Demam Berdarah Dengue dengan motivasi melakukan pencegahan demam berdarah dengue dengan arah hubungan positif dan kekuatan hubungan pada tingkat kuat (nilai $r=0,563$; nilai $p=0,001)$. Hal ini menguatkan bahwa pengetahuan berdampak pada motivasi masyarakat untuk melakukan pencegahan DBD.

Penelitian Hasyim (2013), tentang faktor-faktor yang berhubungan dengan tindakan PSN DBD, memperoleh hasil bahwa terdapat hubungan bermakna antara tingkat pengetahuan responden dengan tindakan PSN DBD $(p=0,000)$, didapatkan hubungan yang bermakna antara sikap dengan tindakan PSN DBD $(p=0,000)$ dan didapatkan hubungan yang bermakna antara pekerjaan dengan tindakan PSN DBD $(p=0,03)$. Dari penelitian ini terbukti bahwa tingkat pengetahuan berhubungan dengan tindakan PSN.

Penelitian Anggraeni, Heridadi dan Widana (2018), tentang analisis faktor risiko KLB DBD di Kecamatan Cikupa Kabupaten Tangerang dilihat dari keberadaan breeding places, resting places, perilaku kesehatan lingkungan dan kebiasaan hidup. Hasil penelitian menunjukkan bahwa 
breeding places $\geq 3$ (OR $=8,531, \mathrm{Cl}$ : $95 \% ; 3,431-21,209)$, resting places $\geq 4 \quad(\mathrm{OR}=2,719$, Cl 95\%; 1,2955,709), perilaku kesehatan lingkungan yang buruk (OR $=8,500$, $95 \% \quad \mathrm{Cl} ; 3,752-19,394)$ dan kebiasaan hidup tidak sehat (OR= 3,763 , Cl: 95\%; 1,722-8,226) berisiko terhadap KLB DBD di Kecamatan Cikupa Kabupaten Tangerang.

Berdasarkan hasil studi pendahuluan wawancara pada warga Desa Kenokorejo, warga mengatakan bahwa hampir setiap tahun ada warga yang terserang penyakit demam berdarah. Sedangkan studi pendahuluan menggunakan kuesioner dari lima warga Desa Kenokorejo dua orang memiliki pengetahuan yang baik dan tiga orang memiliki pengetahuan yang kurang tentang penyakit demam berdarah, penularan dan pencegahan demam berdarah.

Dari hasil wawancara juga diperoleh informasi bahwa untuk menguras bak mandi, warga menunggu bak mandi tersebut terlihat kotor dan muncul banyak jentik. Selain itu warga juga jarang sekali menaburkan larvasida ke tempat penampungan air serta mengaku masih suka menggantung pakaian.

Berdasarkan uraian di atas maka penulis tertarik melakukan penelitian dengan judul "Hubungan Tingkat Pengetahuan tentang Penyakit DBD dengan Tindakan Pemberantasan Sarang Nyamuk".

Penelitian ini adalah replikasi dari penelitian-penelitian yang terdahulu. Perbedaan penelitian ini dengan penelitian sebelumnya adalah pada populasi dan lokasi penelitian, dimana belum pernah dilakukan penelitian untuk variabel tingkat pengetahuan dan tindakan pemberantasan sarang nyamuk di Desa Kenokorejo Kabupaten Sukoharjo yang peneliti ketahui.

\section{TUJUAN PENELITIAN}

Penelitian ini secara umum bertujuan untuk mengetahui hubungan antara tingkat pengetahuan tentang DBD dengan tindakan PSN.

\section{METODE}

Penelitian ini merupakan penelitian korelasi dengan pendekatan cross sectional untuk mengetahui hubungan tingkat pengetahuan tentang DBD dengan tindakan PSN. Responden penelitian adalah warga masyarakat Desa Kenokorejo sejumlah 47 orang. Alat ukur penelitian adalah kuesioner dan data dianalisa menggunakan uji Pearson Correlation.

\section{HASIL PENELITIAN}

Berdasarkan penelitian yang telah dilakukan didapatkan karakteristik responden sebagai berikut :

Tabel 1.

Distribusi Frekuensi Karakteristik Responden

\begin{tabular}{ccc}
\hline Karakteristik & $\mathrm{f}$ & $\%$ \\
\hline Usia (tahun) & & \\
$<20$ & 1 & 2,1 \\
$20-30$ & 1 & 2,1 \\
$31-40$ & 10 & 21,3 \\
$41-50$ & 17 & 36,2 \\
$51-60$ & 12 & 25,5 \\
$>60$ & 6 & 12,8 \\
Jenis Kelamin & & \\
Laki-laki & 29 & 61,7 \\
Perempuan & 18 & 39,3 \\
Pendidikan & & \\
Dasar & 32 & 68,1 \\
Menengah & 13 & 27,6 \\
Tinggi & 2 & 4,3 \\
Pekerjaan & & \\
Buruh & 13 & 27,7 \\
Wiraswasta & 15 & 31,9 \\
Karyawan & 3 & 6,4 \\
swasta & & 29,8 \\
Petani & 14 & 4,2 \\
Pensiunan & 2 &
\end{tabular}


Tabel 2.

Distribusi FrekuensiTingkat Pengetahuan dan Tindakan PSN

\begin{tabular}{|c|c|c|c|}
\hline Variabel & Kategori & $f$ & $\%$ \\
\hline Tingkat & Baik & 45 & $\overline{95,7}$ \\
\hline Pengetahuan & Buruk & 2 & 4,3 \\
\hline Tindakan & Baik & 25 & 53,2 \\
\hline PSN & Cukup & 19 & 40,4 \\
\hline & Kurang & 3 & 6,4 \\
\hline \multicolumn{2}{|c|}{ Jumlah } & 47 & 100 \\
\hline
\end{tabular}

Berdasarkan hasil analisis diketahui sebagai berikut:

Tabel 3.

Hasil Analisis Hubungan Tingkat

Pengetahuan tentang DBD dengan Tindakan PSN

\begin{tabular}{|c|c|c|c|c|}
\hline \multirow{2}{*}{$\begin{array}{c}\text { Tingkat } \\
\text { Pengetahuan }\end{array}$} & \multicolumn{3}{|c|}{ Pelaksanaan PSN } & \multirow{2}{*}{$p$} \\
\hline & Baik & Cukup & Kurang & \\
\hline Baik & $\begin{array}{c}24 \\
(51)\end{array}$ & $\begin{array}{c}18 \\
(38,3)\end{array}$ & $\begin{array}{c}3 \\
(6,4)\end{array}$ & \\
\hline Buruk & $\begin{array}{c}1 \\
(2,2) \\
\end{array}$ & $\begin{array}{c}1 \\
(2,2)\end{array}$ & $\begin{array}{c}0 \\
(0) \\
\end{array}$ & 0,367 \\
\hline Jumlah & $\begin{array}{c}25 \\
(53,2)\end{array}$ & $\begin{array}{c}19 \\
(40,5)\end{array}$ & $\begin{array}{c}3 \\
(6,4)\end{array}$ & \\
\hline
\end{tabular}

Dari tabulasi silang antara tingkat pengetahuan DBD dengan tindakan pemberantasan sarang nyamuk diperoleh hasil bahwa terdapat 45 $(95,7 \%)$ responden dengan tingkat pengetahuan baik dengan pelaksanaan PSN baik sejumlah 24 (51\%), pelaksanaan PSN cukup sejumlah $18(38,3 \%)$, pelaksanaan PSN kurang sejumlah 3 (6,4\%). Sedangkan responden dengan tingkat pengetahuan buruk berjumlah $2 \quad(4,3 \%)$ dengan pelaksanaan baik dan cukup masing-masing 1 responden (2,2\%). Hasil analisis Pearson Correlation diketahui $p=0,367$ sehingga diketahui tidak ada hubungan antara tingkat pengetahuan tentang penyakit Demam Berdarah Dengue dengan tindakan Pemberantasan Sarang Nyamuk.

\section{PEMBAHASAN}

Secara teori tingkat pengetahuan akan mempengaruhi perilaku seseorang. Menurut Fitriani (2011), pengetahuan merupakan hasil dari tahu, setelah orang melakukan penginderaan terhadap suatu objek tertentu. Penginderaan terjadi melalui panca indera manusia, yakni indera penglihatan, pendengaran, penciuman, rasa dan raba. Sebagian besar pengetahuan diperoleh melalui mata dan telinga. Pengetahuan atau kognitif merupakan domain yang sangat penting dalam membentuk tindakan seseorang (overt behavior). Dari definisi pengetahuan tersebut sangat jelas bahwa tindakan seseorang (overt behavior), didasari pengetahuan atau kognitif yang merupakan domain yang sangat penting dalam membentuk tindakan seseorang.

Adapun pada penelitian ini hasil analisis dengan Pearson correlation untuk mengetahui hubungan variabel tingkat pengetahuan DBD dengan tindakan PSN diperoleh nilai $p=0,367$. Dari hasil tersebut dapat disimpulkan bahwa tidak ada hubungan antara tingkat pengetahuan DBD dengan tindakan atau perilaku PSN.

Perilaku adalah respon individu terhadap suatu stimulus atau suatu tindakan yang dapat diamati dan mempunyai frekuensi spesifik, durasi dan tujuan baik disadari maupun tidak. Perilaku dipengaruhi oleh beberapa faktor yaitu faktor internal dan faktor eksternal (Wawan dan Dewi, 2010). Hasil penelitian ini menunjukkan bahwa sebagian besar responden memiliki tingkat pengetahuan baik sejumlah 45 $(95,7 \%)$, disisi yang lain tingkat pendidikan mayoritas responden adalah pendidikan dasar yaitu SD dan SMP sejumlah 32 (68,1\%). Secara teori pendidikan akan mempengaruhi pengetahuan yang kemudian memberikan kontribusi kuat pada perilaku seseorang. Akan tetapi hal tersebut tidak ditemukan pada penelitian ini 
Hal tersebut sesuai dengan penelitian yang dilakukan oleh Monatung (2012), memperoleh hasil bahwa tidak terdapat hubungan yang bermakna antara pendidikan dengan tindakan masyarakat dalam pencegahan DBD. Kemudian disimpulkan bahwa seseorang dengan pendidikan rendah dapat melakukan tindakan pencegahan yang hampir sama baiknya dengan mereka yang berpendidikan tinggi dalam hal tindakan pencegahan DBD. Hasil yang sejalan juga dengan penelitian Harmani dan Hamal (2013), yang menunjukkan tidak adanya hubungan yang bermakna antara pendidikan dengan perilaku ibu dalam pencegahan penyakit DBD $(p=0,080)$. Responden yang berpendidikan lain dari orang yang bersangkutan. Hal tersebut sesuai dengan paparan Notoatmodjo (2010), yang menyebutkan bahwa faktor yang mempengaruhi perilaku seseorang meliputi faktor internal dan eksternal. Faktor internal, yaitu karakteristik orang yang bersangkutan, misalnya: tingkat pendidikan, tingkat emosional, jenis kelamin dan sebagainya. Faktor eksternal, yaitu lingkungan baik lingkungan fisik, sosial, budaya, ekonomi. Adapun faktor lingkungan merupakan faktor yang dominan mempengaruhi perilaku seseorang. Menurut Muslimin (2015), salah satu faktor yang kuat mempengaruhi perilaku kesehatan masyarakat adalah faktor budaya. Dimana disebutkan bahwa budaya merupakan keseluruhan yang kompleks yang didalamnya terkandung ilmu pengetahuan, kepercayaan, kesenian, moral, hukum dan adat istiadat. Kebudayaan adalah seluruh kelakuan dan hasil kelakuan manusia yang teratur oleh tata kelakuan yang harus didapatkannya dengan belajar dan semuanya dasar pun ada yang berperilaku baik. Hal ini disebabkan karena responden sering mendapatkan informasi tentang upaya-upaya pencegahan penyakit DBD melalui petugas kesehatan, leaflet, brosur, media cetak, televisi dan radio. Dari uraian tersebut menunjukkan bahwa pendidikan tidak berhubungan dengan tindakan PSN. Hal ini dapat dipahami, karena banyak faktor yang mempengaruhi perilaku seseorang dalam lingkungan masyarakat. Hal tersebut sesuai dengan paparan Notoatmodjo (2012), yang menyebutkan perilaku adalah bentuk respons atau reaksi terhadap stimulus atau rangsangan dari luar organisme, namun dalam memberikan respon tergantung pada karakteristik atau faktor-faktor tersusun dalam kehidupan masyarakat. Berdasarkan uraian tersebut maka dapat dipahami bahwa masing-masing komunitas atau masyarakat memiliki kultur yang berbeda-beda yang mempengaruhi perilaku mereka termasuk di dalamnya perilaku kesehatan.

Berdasarkan uraian tersebut cukup jelas mengapa perilaku responden yang mayoritas $(68,1 \%)$, memiliki pengetahuan yang baik tentang DBD memiliki perilaku tentang PSN kategori cukup sebesar $40,5 \%$ dan kategori kurang sebesar $6,4 \%$. Dapat ditarik kesimpulan bahwa ada faktor yang lain yang mempengaruhi perilaku responden. Hal tersebut sesuai dengan paparan Notoatmodjo (2010), bahwa faktor yang dominan memberikan pengaruh terhadap perilaku seseorang adalah faktor eksternal, yaitu lingkungan baik lingkungan fisik, sosial, budaya, serta ekonomi. Dari uraian tersebut dimungkinkan bahwa lingkungan eksternal baik lingkungan fisik, sosial budaya ataupun ekonomi berpengaruh pada perilaku responden, akan tetapi 
variabel tersebut tidak diteliti pada penelitian ini.

Disisi yang lain perilaku seseorang akan diawali dengan menentukan sikap terlebih dahulu terhadap suatu hal, termasuk dalam hal ini adalah sikap terhadap DBD dan PSN. Hal tersebut senada dengan Notoatmodjo (2012), yang menyebutkan sikap merupakan reaksi atau respons yang masih tertutup dari seseorang terhadap suatu stimulus atau objek. Adapun tingkatan sikap meliputi menerima (receiving) stimulus yang diberikan, merespon (responding), menghargai (valuing) dan bertanggungjawab.

Notoatmodjo (2012), menyebutkan bahwa suatu sikap belum otomatis terwujud dalam suatu tindakan. Untuk mewujudkan sikap menjadi perbuatan nyata diperlukan faktor pendukung atau suatu kondisi yang memungkinkan. Diantaranya adalah faktor fasilitas dan faktor dukungan. Dari uraian ini dapat dimengerti bahwa responden pada penelitian ini mayoritas memiliki pengetahuan tentang DBD dalam kategori yang baik akan tetapi memiliki perilaku yang kurang dalam PSN.

Masyarakat dengan pengetahuan yang tinggi tentang DBD belum tentu melakukan tindakan PSN, salah satu penyebabnya adalah kurangnya dukungan atau stimulasi yang menggugah dan menyadarkan mereka. Penelitian Prasetyowati, Santya dan Nurindra (2015), menyebutkan bahwa perlu adanya motivasi untuk meningkatkan kesadaran masyarakat menjalankan PSN, seperti kegiatan pemicuan kesadaran warga yang dilaksanakan dalam forum pertemuan warga. Dalam pertemuan ini dapat disampaikan pemaparan hasil survai jentik yang telah dilakukan, pengenalan Aedes aegypti, perkembangan kasus DBD dan upaya-upaya yang telah dilakukan oleh masyarakat dan petugas Puskesmas. Dalam pertemuan ini warga dapat secara aktif menyampaikan pendapat serta pengalaman saat ada keluarga yang sakit atau mengalami sakit, termasuk kerugian yang di sebabkan oleh sakit DBD. Dalam kegiatan pemicuan ini dilakukan dialog dengan warga mengenai risiko dan bahaya DBD. Pada akhirnya muncul kesadaran warga dan warga berkomitmen bahwa DBD merupakan masalah bersama yang harus segera ditanggulangi bersama, adanya kesepakatan pemeriksaan jentik berkala yang dilakukan oleh para pemuda perwakilan setiap RT, adanya kesepakatan perlunya sanksi pada masyarakat jika dirumahnya ditemukan jentik, mengaktifkan kembali kader, satgas Pemberantasan Sarang Nyamuk, diperoleh kesepakatan waktu untuk mulai dilakukan pemeriksaan jentik berkala di lingkungan tempat tinggal warga.

Hasil penelitian tersebut menjelaskan bahwa di dalam masyarakat tidak cukup hanya memberikan edukasi untuk meningkatkan pengetahuan saja. Tindakan paska edukasi yang dapat meningkatkan motivasi dan dorongan sangat penting sehingga masyarakat melaksanakan PSN. Hal ini menjadi dasar bagi petugas kesehatan untuk melakukan berbagai macam pendekatan atau metode kreatif untuk mengubah perilaku masyarakat.

Salah satu metode meningkatkan peran serta masyarakat untuk melakukan PSN adalah melakukan pemantauan secara berkala oleh petugas atau kader kesehatan. Hal ini dapat meningkatkan pelaksanaan kegiatan PSN seperti paparan Agustini (2015), bahwa untuk optimalisasi kegiatan PSN diperlukan advokasi untuk penambahan sumber daya manusia dari luar kader Posyandu dan kelompok dasawisma. Selain itu, 
dapat dilakukan Lomba Kampung Bebas Jentik untuk memotivasi kader dan warga. Sedangkan menurut Lesmana, Susanty dan Afandi (2020), dapat dilakukan dengan optimalisasi Program Saruju (satu rumah satu jumantik).

Kesimpulan yang dapat diambil adalah bahwa perilaku PSN masyarakat tidak hanya dipengaruhi pengetahuan tentang DBD saja, tetapi multifaktorial. Banyak faktor yang mempengaruhinya. Upaya meningkatkan kegiatan PSN untuk menekan DBD perlu berbagai strategi dan pemberdayaan masyarakat. Sukesi, et al. (2018), menyebutkan bahwa pemberdayaan masyarakat dalam pengendalian DBD diperlukan karena pemerintah tidak bisa berjalan sendiri dalam upaya pengendalian DBD. Semua program yang digulirkan akan tidak berguna apabila masyarakat tidak dilibatkan dalam perencanaan, proses monitoring dan evaluasi. Hal ini disebabkan karena DBD berhubungan dengan masalah lingkungan dimana manusia terlibat dalam menciptakan lingkungan yang mendukung terhadap penyebaran penyakit DBD. Pemberdayaan masyarakat dalam pengendalian DBD penting untuk menunjang pelaksanaan dan keberlangsungan program pengendalian DBD.

\section{KESIMPULAN}

Tidak ada hubungan antara tingkat pengetahuan Demam Berdarah Dengue dengan tindakan Pemberantasan Sarang Nyamuk ( $p$ $=0,367)$.

\section{SARAN}

Masyarakat perlu meningkatkan kesadaran tentang pentingnya melaksanakan PSN untuk mencegah kejadian penyakit DBD dan Perawat khususnya dalam lingkup komunitas lebih meningkatkan perannya terutama mengedukasi masyarakat terkait pentingnya PSN. Selain itu perlu penguatan serta motivasi secara terus-menerus bagi masyarakat sehingga melakukan PSN.

\section{DAFTAR PUSTAKA}

Agustini, R. T. 2015. Evaluasi Pemeriksaan Jentik Berkala Rumah Warga di Wilayah Puskesmas Tanah Kalikedinding Surabaya. https://ejournal.unair.ac.id/PROMKES/ar ticle/view/4467. Diakses pada tanggal 14 Maret 2020.

Anggraeni, P., Heridadi dan I. K. Widana. 2018. Faktor Risiko (Breeding Places, Resting Places, Perilaku Kesehatan Lingkungan dan Kebiasaan Hidup) pada Kejadian Luar Biasa Demam Berdarah Dengue di Kecamatan Cikupa Kabupaten Tangerang. http://jurnalprodi.idu.ac.id/. Diakses pada tanggal 20 Februari 2019.

Depkes RI. 2019. Kasus DBD Terus Bertambah.

http://www.depkes.go.id/. Diakses pada 6 Maret 2019.

Dinkes Provinsi Jawa Tengah. Profil Kesehatan Provinsi Jawa Tengah Tahun 2017. http://www.depkes.go.id/. Diakses pada 6 Maret 2019.

Fitriani, S. 2011. Promosi Kesehatan. Graha IImu, Yogyakarta.

Hasyim, D. M. 2013. Faktor-Faktor yang Berhubungan dengan Tindakan Pemberantasan Sarang Nyamuk Demam Berdarah Dengue (PSN DBD). https://ejurnal.poltekkestjk.ac.id/. Diakses pada tanggal 23 Februari 2019.

$\begin{array}{ccc}\text { Harmani, } & \mathrm{N}, \quad \text { dan } & \text { D. K. K. } \\ \text { Hamal. } & \text { 2013. Hubungan } \\ \text { antara Karakteristik Ibu } \\ \text { dengan Perilaku Pencegahan } \\ \text { Penyakit } D B D \text { di Kabupaten } \\ \text { Karang Tengah Kecamatan }\end{array}$


Cianjur Provinsi Jawa Barat tahun 2013. FIKES UHAMKA. https://docplayer.info/37478300Hubungan-antara-karakteristikibu-dengan-perilakupencegahan-penyakit-dbd-dikecamatan-karang-tengahkabupaten-cianjur-provinsijawa-barat-tahun-2013.html. Diakses pada tanggal 16 Februari 2020.

Lestari, T. 2016. Asuhan Keperawatan Anak. Nuha Medika, Yogyakarta.

Lesmana, S.D., E. Susanty, D. Afandi 2020. Gerakan Satu Rumah Satu Jumantik (Saruju) di Kampung Pelita Medika II Buluh Cina Kabupaten Kampar. ETHOS Jurnal Penelitian dan Pengabdian Kepada Masyarakat.

https://ejournal.unisba.ac.id/inde x.php/ethos/article/view/5249.

Diakses pada tanggal 12 April 2020.

Monatung, D. 2012. Hubungan Antara Karakteristik Individu, Pengetahuan, Sikap dengan Tindakan Masyarakat dalam Pencegahan Demam Berdarah Dengue di Wilayah Kerja Puskesmas Kolongan Minahasa Utara. Thesis. Universitas Sam Ratulangi Manado.

https://ejournal.unsrat.ac.id/inde x.php/jikmu/article/download/78 59/7423. Diakses 3 Februari 2020.

Muslimin. 2015. Perilaku Antropologi Sosial Budaya dan Kesehatan. https://books.google.co.id/books ?id=DaOMDwAAQBAJ\&printse $\mathrm{c}=$ frontcover\&dq=muslimin + buk u+kesehatan\&hl=id\&sa=X\&ved $=0$ ahUKEwj84bPz oAhXPX3 OKHSOQBUAQ6AEIKDAA. Diakses 12 April 2020.

Notoatmodjo, S. 2010. IImu perilaku Kesehatan. Rineka Cipta, Jakarta.
2012. Kesehatan
Masyarakat IImu dan Seni.
Rineka Cipta, Jakarta.

Nuryanti, E. 2013. Perilaku Pemberantasan Sarang Nyamuk di Masyarakat. https://journal.unnes.ac.id/.

Diakses pada tanggal 20 Februari 2019.

Prasetyowati, H., R. N. R. E. Santya dan R. W. Nurindra. 2015. Motivasi dan Peran Serta Masyarakat dalam Pengendalian Populasi Aedes SPP di Kota Sukabumi. https://www.neliti.com/id/publica tions/81762/motivasi-dan-peranserta-masyarakat-dalampengendalian-populasi-aedesspp-di-kot. Diakses pada tanggal 5 Januari 2020.

Sejati, E.W., S. D. Sulisetyawati dan Y. Nurhayati. 2014. Hubungan Pengetahuan Tentang Demam Berdarah Dengue dengan Motivasi Melakukan Pencegahan DBD. http://digilib.stikeskusumahusad a.ac.id/. Diakses pada tanggal 23 Februari 2019.

Sukesi, et al. 2018. Pemberdayaan Masyarakat dalam Pengendalian Demam Berdarah Dengue (Literatur Review). Jurnal Vektor Penyakit. Vol. 1. https://www.google.com/search ?safe=strict\&sxsrf=ALeKk02Xv0 tpgM9iqepC82UeTukfH2vEg:15 87696623175\&q=Pemberdayaa $\mathrm{n}+$ Masyarakat+dalam+Pengend alian+Demam+Berdarah+Deng $\mathrm{ue}+($ Literature+Review $) \&$ spell $=1$ \&sa $=$ X\&ved=2ahUKEwiE3PDph oDpAhWNA3IKHSP7AGcQkeE CKAB6BAgLECo. Diakses pada tanggal 21 April 2020.

Wawan, A. dan Dewi M. 2010. Teori dan Pengukuran Pengetahuan, Sikap, dan Perilaku Manusia. Nuha Medika, Yogyakarta. 